\title{
MENUMBUH KEMBANGKAN \\ KEMAMPUAN KOMUNIKASI MATEMATIS SISWA MELALUI PENERAPAN MODEL PEMBELAJARAN CREATIVE PROBLEM SOLVING DENGAN MEDIA GONGGONG
}

\author{
Agustina Sri Wardani ${ }^{1}$, Nur Izzati $^{2}$ \\ gustinaswd@gmail.com²1, nurizzati@umrah.ac.id ${ }^{2}$ \\ ${ }^{1)}$ Mahasiswa Prodi Pendidikan Matematika FKIP UMRAH \\ ${ }^{2)}$ Dosen Prodi Pendidikan Matematika FKIP UMRAH
}

\begin{abstract}
ABSTRAK
Matematika merupakan mata pelajaran yang didapat siswa pada setiap jenjang pendidikan. Mulai dari pendidikan dasar sampai pendidikan tinggi. Berdasarkan Permendikbud Nomor 59 Tahun 2014, salah satu tujuan pembelajaran matematika adalah untuk melatih komunikasi matematis siswa. Kemampuan komunikasi matematis penting dimiliki siswa. Dengan dimilikinya kemampuan ini oleh siswa, mereka akan menjadi terbiasa dengan simbol-simbol, diagram, table, grafik, ataupun gambar. Penulisan artikel ini bertujuan untuk memaparkan secara teoritis tentang menumbuhkembangkan kemampuan komunikasi matematis siswa melalui penggunaan model pembelajaran Creative Problem Solving (CPS) dengan Menggunakan Media Gonggong.
\end{abstract}

Kata kunci: Kemampuan Komunikasi Matematis, Creative Problem Solving (CPS), Media Gonggong.

\section{PENDAHULUAN}

Matematika ialah mata pelajaran yang didapat siswa pada setiap jenjang pendidikan. Mulai dari pendidikan dasar sampai pendidikan tinggi. Matematika merupakan satu diantara sarana-sarana yang penting dalam upaya untuk meningkatkan kemampuan dan keterampilan intelektual (Purwanto, 2017:1). Dengan belajar matematika seorang siswa akan memiliki kemampuan dalam berfikir logis, sistematis, analitis, kreatif dan kritis, serta kemampuan untuk bekerjasama (Utomo, dkk., 2015:1).

Salah satu tujuan pembelajaran matematika berdasarkan Peraturan Menteri Pendidikan dan Kebudayaan Republik Indonesia nomor 58 tahun 2014 adalah agar siswa dapat mengomunikasikan gagasan, penalaran serta mampu menyusun bukti matematika dengan menggunakan kalimat lengkap, simbol, tabel, diagram, atau media lain untuk menjelaskan keadaan atau masalah 
(Kementerian Pendidikan dan

Kebudayaan, 2016:16).

Terdapat dua standar pembelajaran dalam National Council of Teachers of Mathematics (NCTM), standar isi dan standar proses. Standar isi adalah standar dalam pembelajaran matematika yang berisi konsep-konsep yang harus dipelajari siswa (NCTM, 2000:3). Standar isi meliputi angka dan operasi, aljabar, geometri, pengukuran, serta analisis data dan peluang. Sedangkan standar proses adalah standar pembelajaran matematika yang berisi cara memperoleh dan menerapkan standar isi. Standar proses meliputi penyelesaian masalah (problem solving), penalaran dan bukti (reasoning dan proof), komunikasi (communication), koneksi (connections), dan representasi (representations). Salah satu standar yang ada dalam standar proses adalah komunikasi (communication) (NCTM, 2000:4).

Dari penjelasan di atas, peneliti menarik kesimpulan bahwa kemampuan komunikasi matematis harus dimiliki siswa. Namun kenyataannya, berdasarkan observasi di sebuah sekolah di Tanjungpinang, peneliti melihat bahwa tingkat komunikasi matematis siswa masih tergolong rendah. Siswa masih sangat susah menyelesaikan soal cerita. Bahkan peneliti mendapati, siswa langsung menyerah ketika diberikan sebuah soal cerita, tanpa lebih dulu mereka coba kerjakan. Ketika diberikan soal dapat siswa dapat menyelesaikannya, namun ketika konsep matematika itu dijabarkan kedalam bentuk cerita, siswa masih kebingungan konsep apa yang digunakan untuk dapat menyelesaikan soal tersebut.

Komunikasi diperlukan untuk bersosialisasi dengan orang lain. Agar mencapai pembelajaran yang mengasikkan dan efektif seorang guru haarus terlatih merancang proses pembelajaran secara jeli. Guru harus selalu berusaha menyusun dan menetapkan model-model mengajar yang efektif dan efisien guna memperoleh keberhasilan dalam menggapai tujuan pendidikan (Ngalimun, 2017:6). Melalui model pembelajaran Creative Problem Solving (CPS) menggunakan media gonggong sebagai salah satu khas masyarakat Tanjungpinang yang langsung terkait kehidupan nyata siswa, diharapkan kemampuan komunikasi siswa berhasil tumbuh juga berkembang. Tujuan penulisan artikel ilmiah non penelitian ini adalah untuk memaparkan secara teoritis tentang menumbuhkembangkan kemampuan komunikasi matematis siswa melalui penerapan model pembelajaran, 
yaitu model pembelajaran Creative Problem Solving (CPS). dengan menggunakan media gonggong yang merupakan salah satu khas masyarakat Tanjungpinang.

\section{PEMBAHASAN}

\section{Komunikasi}

Komunikasi ialah proses pemberitahuan gagasan dari seseorang kepada orang lain (Majid, 2015:282). Komunikasi ialah tindakan melakukan kontak antara si pengirim dan si penerima, dengan pertolongan pesan. Pengirim dan penerima mempunyai beberapa pengalaman bersama-sama yang memberikan arti pada pesan serta simbol yang dikirim oleh pengirim, kemudian diterima dan ditafsirkan oleh penerima (Wilbur Schramm dalam El Khuluqo, 2017:97). Dari pendapat para ahli di atas, dapat disimpulkan komunikasi adalah tindakan pengiriman gagasan dari pengirim pesan kepada penerima pesan agar pengirim pesan dan penerima pesan mempunyai kesamaan arti dalam gagasan yang disampaikan.

Tujuan komunikasi antara lain (El Khuluqo, 2017:102-103), yaitu: (1) Agar yang kita sampaikan dapat dimengerti, sebagai komunikator kita haruslah menyampaikan informasi secara jelas kepada komunikan (penerima).

Mengerti orang lain. Komunikator haruslah memahami apa yang sebenarnya diinginkan masyarakat. (3) Lakukan pendekatan persuasif agar gagasan yang kita berikan dapat diterima orang lain. Jangan memaksa kehendak pribadi. (4) Membuat orang lain bersedia untuk melaksanakan sesuatu. Menggerakkan dapat bermacam-macam, misalnya kegiatan. Jika ingin menggerakkan suatu kegiatan, ingatlah lakukan dengan cara yang baik.

\section{Komunikasi Matematis}

Kemampuan komunikasi matematis ialah kemampuan menyampaikan ide matematika dalam permasalahan nyata dalam kehidupan sehari-hari melalui grafik atau gambar, table, persamaan aljabar, atau dengan bahasa sehari-hari (I. Ansari, 2016:16-17). Kemampuan komunikasi matematis merupakan suatu kemampuan siswa dalam menyampaikan suatu hal diketahuinya melalui dialog di kelas, dimana terjadi pengalihan pesan. Pesan yang dialihkan berisi materi-materi matematika yang dipelajari siswa, bisa berupa konsep, rumus, atau strategi penyelesaian suatu masalah (Saputra, 2012:3). Dari penjabaran di atas, disimpulkan bahwa kemampuan 
komunikasi matematis adalah komunikasi matematis adalah gagasan untuk menuangkan ide ataupun pengetahuan melalui simbol, diagram, table, grafik, ataupun gambar.

\section{Untuk mengembangkan}

kemampuan komunikasi matematis, para siswa perlu menyampaikan informasi dengan bahasa matematika, contohnya menyajikan suatu permasalahan dalam bentuk model matematik yang dapat berupa diagram, persamaan, grafik, atau tabel (I. Ansari, 2016:27).

\section{Mengomunikasikan}

dan menegosiasikan ide dengan bahasa matematis akan membuat pembelajaran lebih praktis, sistematis, juga efisien. Mengomunikasikan gagasan dengan bahasa matematika dapat mengubah situasi pembelajaran, dari siswa yang pasif menjadi aktif, dari proses dan hasil belajar tunggal menjadi bermacam cara dan penyelesaian.

Selain itu, adanya kesempatan bagi siswa untuk mengomunikasikan apa yang dipikirkannya, membuat guru mengetahui sejauh mana pemahaman siswanya terhadap topik tertentu, dan apa permasalahan yang dihadapi oleh siswanya. Dengan demikian guru dapat memberikan bantuan yang tepat dan mengantisipasi timbulnya masalah berikutnya (Izzati, 2012:32).
Indikator ketercapaian kemampuan komunikasi matematis siswa dalam tujuan pembelajaran matematika nasional adalah: (1) Memberikan alasan ataupun buktibukti terhadap kebenaran suatu pernyataan. (2) Menduga serta memeriksa kebenaran suatu pernyataan (conjecture). (3) memeriksa kesahihan ataupun kebenaran suatu argument dengan penalaran induksi. (4) menurunkan ataupun membuktikan rumus-rumus dengan penalaran deduksi. (5) menduga serta memeriksa kebenaran dugaan (conjecture).

Indikator kemampuan siswa dalam komunikasi matematis dalam pembelajaran matematika (NCTM, 2003:2) dapat dilihat dari (1) kemampuan mengkomunikasikan ide-ide matematis secara jelas kepada teman-teman sebaya, teman-teman satu sekolah, dan orang lain disekitarnya. (2) Kemampuan berbahasa matematika untuk mengekspresikan ide secara tepat. (3) Kemampuan mengorganisasikan pemikiran matematika melalui komunikasi. (4) Kemampuan menganalisa juga mengevaluasi kemampuan matematika dan strategi yang lainnya.

Indikator ketercapaian kemampuan komunikasi matematis yang digunakan dalam artikel ini mengacu pada indikator 
NCTM karena aspek-aspek

ketercapaiannya cukup jelas.

\section{Model Pembelajaran}

Model pembelajaran ialah suatu perencanaan yang dibuat guna sebagai pedoman untuk merancang pembelajaran di dalam kelas (Ngalimun, 2017:37). Model pembelajaran ialah kerangka konseptual yang digunakan sebagai panduan pengajaran yang dimanfaatkan seorang guru untuk menolong siswa memperoleh informasi baru (Rahayu, 2015:2). Dari pendapat yang telah dipaparkan, dapat ditarik kesimpulan model pembelajaran ialah suatu perencanaan terkonsep yang digunakan sebagai pedoman dalam pembelajaran di kelas untuk menolong siswa mendapatkan informasi yang baru.

Model pembelajaran berfungsi sebagai pedoman perencanaan juga pelaksanaan pembelajaran. Penggunaan model pembelajaran harus memperhatikan sifat materi yang akan diajarkan, tujuan pembelajaran, dan tingkat kemampuan siswa (Ngalimun, 2017:39).

\section{Model Pembelajaran Creative Problem Solving (CPS)}

Creative Problem Solving (CPS) ialah model pembelajaran berlandaskan pemecahan masalah melalui teknik yang sistematik dalam mengorganisasikan gagasan kreatif yang berguna untuk menyelesaikan permasalahan (Ngalimun, 2017:339). Menurut Osborn-lah Creative Problem Solving (CPS) ialah model pembelajaran untuk menyelesaikan masalah secara kreatif (Rusman, 2014:298). Dapat disimpulkan, Creative Problem Solving (CPS) adalah sebuah model pembelajaran untuk pemecahan masalah dengan kreatif melalui teknik yang sistematik.

Tujuan utama menggunakan Creative Problem Solving (CPS) dalam pembelajaran adalah untuk memberdayakan menggunakan metode dan strategi, bekerja sendiri atau di dalam kelompok, untuk mengetahui sesuatu yang penting dan melatih mereka menemukan dalam kehidupan nyata (J. Treffinger, 2000:4)

Berikut sintak proses Creative Problem Solving (CPS) OFPISA model Osborn-Parnes (Huda, 2014: 298), yaitu: (1) Objective Finding. Siswa dibagi menjadi kelompok-kelompok. Guru memberikan sebuah masalah untuk didiskusikan siswa. Guru membrainstorming sejumlah tujuan atau sasaran yang dapat digunakan untuk kerja kreatif siswa. Dalam kegiatan ini, 
diharapkan siswa dapat membuat suatu consensus tentang sasaran yang hendak dicapai oleh kelompoknya. (2) Fact finding. Siswa membrainstorming faktafakta yang mungkin saja berkaitan dengan sasaran kelompoknya. Guru mendaftar setiap pendapat siswa. Guru memberi waktu kepada siswa guna berefleksi tentang fakta-fakta apa saja yang menurut mereka paling relevan dengan sasaran dan solusi permasalahan. (3) Problem finding. Mendefinisikan kembali masalah yang sedang dibahas merupakan salah satu aspek terpenting dari kreativitas, agar siswa menjadi lebih dekat dengan masalah sehingga memungkinkannya untuk menemukan solusi yang lebih jelas. Salah satu teknik yang bisa digunakan adalah brainstorming beragam cara yang mungkin dilakukan untuk semakin memperjelas sebuah masalah. (4) Idea finding. Di tahap ini, gagasan atau ide siswa didaftar untuk dapat melihat kemungkinan menjadi solusi dari situasi permasalahan. Ini merupakan langkah brainstorming yang sangat penting. Usaha-usaha yang diberikan siswa haruslah diapresiasi dengan penulisan setiap gagasan, tidak peduli tingkat kerelevanan gagasan tersebut akan menjadi solusi. Setelah gagasan dan ide tersebut terkumpul, cobalah untuk meluangkan beberapa saat untuk memilih mana saja gagasan yang potensial dan yang tidak potensial sebagai solusi. Tekniknya adalah evaluasi dengan cepat atas gagasan dan ide tersebut untuk menghasilkan hasil sortir gagasan yang kira-kira bisa menjadi pertimbangan solusi lebih lanjut. (5) Solution finding. Di tahap ini, gagasan atau ide yang memiliki potensi paling besar dievaluasi bersama. Salah satu caranya bisa dengan membrainstorming kriteria-kriteria yang dapat menentukan seperti apa solusi yang terbaik itu seharusnya. Kriteria ini dievaluasi hingga pada akhirnya menghasilkan penilaian final atas gagasan yang pantas menjadi solusi dari situasi permasalahan. (6) Acceptance finding. Di tahap ini siswa mulai memikirkan isu-isu nyata dengan cara berpikir yang sudah mulai berubah. Diharapkan siswa sudah memiliki cara baru guna menyelesaikan berbagai masalah secara kreatif. Gagaasangagasan mereka diharapkan sudah bisa digunakan, tidak hanya digunakan untuk menyelesaikan masalah namun juga untuk mencapai kesuksesan.

Langkah-Langkah dan Fase-Fase dalam Creative Problem Solving (CPS) (J. Treffinger et al., 2006:19): (1) Pahami permasalahan yang diberikan. Meliputi (a) Membangun peluang. Menghasilkan peluang yang mungkin dan tantangan yang 
dapat dipertimbangkan. Fokus dalam mengidentifikasi masalah yang akan diselesaikan. (b) Memeriksa data. Memeriksa banyaknya sumber data dari sudut pandang yang berbeda. Identifikasikan kunci atau data paling penting. (c) Menyusun masalah. Menghasilkan beragam cara untuk menyatakan masalah. Pilih pernyataan masalah yang spesifik. (2) Menghasilkan ide. Menghasilkan ide yang banyak, bervariasi, dan luar biasa. Identifikasi ideide dengan potensi yang menarik untuk digunakan. (3) Persiapan untuk aksi. Meliputi: (a) Mengembangkan solusi. Temukan jalan untuk mengembangkan kemungkinan yang menjanjikan . analisis, evaluasi, prioritas, dan menyaring kemungkinan yang menjanjikan. (b) Bangun penerimaan. Pertimbangkan berbagai sumber untuk mendukung dan menentang, dan juga kemungkinan berbagai tindakan untuk implementasi. Rumuskan rencana yang spesifik untuk mendapatkan dukungan, melaksanakan, dan mengevaluasi tindakan.

Sintaks model pembelajaran Creative Problem Solving (CPS) yang dimaksud dalam artikel ini, yang merupakan gabungan sintaks-sintaks dari para ahli di atas adalah: (1) Menemukan fakta. Pada tahap ini, guru memberikan sebuah permasalahan. Siswa dituntut untuk dapat mengemukakan dan menemukan fakta-fakta terkait permasalahan yang diberikan. Hal ini penting dilakukan agar menanamkan pengetahuan siswa pada suatu konsep. (2) Menemukan masalah. Pada tahap ini, guru menanggapi faktafakta yang dikemukakan siswa terkait suatu konsep. Siswa diharapkan mampu untuk menemukan masalah apa yang sedang dihadapi. siswa diharapkan mampu memperkirakan cara menyelesaikan masalah yang diberikan. Siswa dituntut berhasil menyelesaikan masalah sesuai tujuan. (3) Menemukan ide. Tahap ini membagi siswa dalam kelompok dan berupaya menemukan untuk bisa menyelesaikan masalah yang diberikan di dalam kolompoknya. (4) Menemukan solusi. Pada tahap ini, gagasan atau ide yang telah ditemukan pada tahap sebelumnya disaring gagasan atau ide untuk mencari alternative jawaban yang tepat yang tepat digunakan untuk menyelesaikan masalah. (5) Menemukan jawaban.Pada tahap ini, guru memberi masukan terhadap pendapat yang diberikan siswa dan memberi pengertian tentang jawaban yang tepat dalam menyelesaikan permasalah yang diberikan. 


\section{Media Gonggong sebagai Khas Masyarakat Tanjungpinang}

Gonggong adalah hasil laut yang sangat banyak terdapat di Kota Tanjungpinang khususnya. Bukan hanya di kota Tanjungpinang, gonggong dapat dijumpai dibeberapa pulau-pulau lainnya di Provinsi Kepulauan Riau. Gonggong adalah makanan yang disukai masyarakat tempatan penduduk Kepulauan Riau, wisatawan domestic maupun mancanegara (Izuan, Viruly, \& Said Raza'i, 2014:3). Bahkan ada wisatawan yang mengatakan "belum ke Tanjungpinang kalau belum mencicipi gonggong." Gonggong adalah tujuan yang wajib terlaksana saat berkunjung ke Kota Tanjungpinang.

Gonggong dipilih untuk dijadikan media pembelajaran dalam artikel ini karena gonggong sangat dekat dengan siswa. Marzolla dan Lloyrd mengatakan ubahlah segala sesuatu yang ada di sekitar siswa menjadi pengalaman belajar (Kosasih, 2016:64). Gonggong atau siput gonggong adalah sejenis siput laut dengan kulit yang tebal (Khadafi, 2008:10). Dalam artikel ini, gonggong akan ditampilkan secara visual. Media ini dibuat dengan software Macromedia Flash 8.

$$
\text { Media visual bisa }
$$

memperlancar pemahaman serta memperkuat ingatan, bisa pula mengembangkan minat belajar siswa dan dapat memberikan hubungan antara isi materi pelajaran dengan kehidupan nyata (Arsyad, 2014:89). Dari pendapat di atas, peneliti menampilkan gonggong melalui media visual.

Gonggong dijadikan sebagai objek dalam permasalahan yang diberikan guru dalam pembelajaran dengan menggunakan model pembelajaran Creative Problem Solving (CPS). Gonggong tidak dibawa secara langsung di dalam kelas, namun divisualisasikan menjadi bentuk visual, dapat diubah menjadi bentuk gambar. Gambar gonggong inilah yang dibawa di dalam kelas. Bisa menggunakan Microsoft PowerPoint ataupun Macromedia Flash. Macromedia Flash bisa dijadikann jawaban tepat untuk membuat animasi. Jadikanlah gonggong sebagai artis di dalam 
kelas. Gonggong inilah yang menjadi topic permasalahan di dalam pembelajaran. Berikut diberikan salah satu contoh media pembelajaran yang menggunakan media Gonggong.

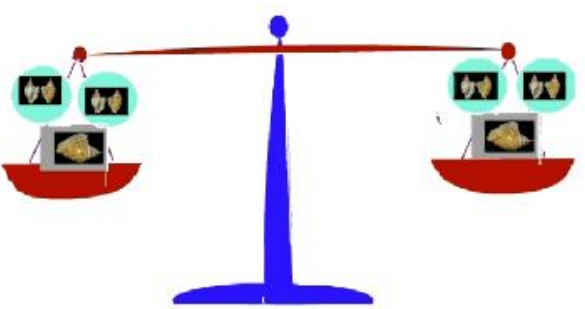

Gambar 1. Media Gonggong

Contoh media Gongong seperti yang ditunjukkan oleh Gambar 1 di atas, digunakan dalam materi persamaan linear satu variabel yang dalam kurikulum 2013 adalah materi pada kelas VII untuk SMP/MTs pada semester ganjil. Media ini digunakan pada sub materi menyelesaikan persamaan dengan operasi penjumlahan atau pengurangan. Timbangan akan mencapai keseimbangan jika kedua lengan memiliki beban yang sama. Jika nanti beban pada timbangan diubah seperti Gambar 2 di bawah ini.

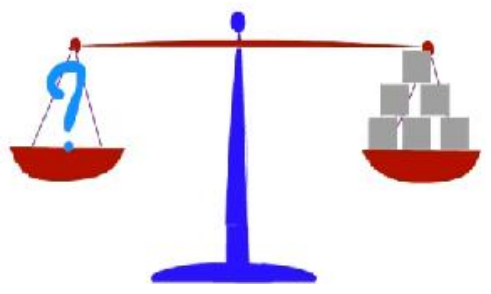

\section{Gambar 2. Permasalahan} Timbangan

Siswa dituntut untuk mencari solusi agar beban di lengan kiri dapat seimbang dengan beban di sebelah kanan.

Dengan dijadikannya gonggong sebagai objek masalah, diharapkan siswa lebih cepat menangkap maksud permasalahan yang diberikan. Diharapkan siswa juga lebih antusias menyelesaikan permasalah yang diberikan.

\section{PENUTUP}

Kemampuan komunikasi matematis penting ditumbuhkembangkan dalam pembelajaran matematika. Salah satu cara yang dianggap tepat untuk dapat menumbuhkembangkan kemampuan komuniaksi matematis ini adalah melalui pemilihan model pembelajaran yang tepat. Salah satu model pembelajaran yang dianggap dapat menjadi wadah untuk 
menumbuhkembangkan kemampuan komunikasi matematis siswa adalah model pembelajaran Creative Problem Solving (CPS) dengan media gonggong. Gonggong dijadikan alat untuk menambah minat belajar siswa. Karena gonggong merupakan salah satu khas masyarakat Tanjungpinang, gonggong adalah barang yang sangat sering dijumpai oleh siswa dalam kehidupan sehari-harinya.

\section{DAFTAR PUSTAKA}

Arsyad, A. (2014). Media Pembelajaran (Revisi, Vol. Cetakan ke-17). Jakarta: PT Rajagrafindo Persada.

El Khuluqo, I. (2017). Belajar dan Pembelajaran. Yogyakarta: Pustaka Pelajar.

Huda, M. (2014). Model-Model Pengajaran dan Pembelajaran (5th ed.). Yogyakarta: Pustaka Pelajar.

I. Ansari, B. (2016). Komunikasi Matematik, Strategi Berpikir dan Manajemen Belajar: Konsep dan Aplikasi (1st ed.). Aceh: PeNA.

Izzati, N. (2012). Peningkatan Kemampuan Komunikasi Matematis dan Kemandirian Belajar Siswa SMP melalui Pendekatan Pendidikan Matematika Realistik.
Disertasi UPI: Tidak diterbitkan.

Izuan, M., Viruly, L., \& Said Raza'i, T. (2014). Kajian Kerapatan Lamun terhadap Kepadatan Siput Gonggong (Strombus epidromis) di Pulau Dompak.

J. Treffinger, D. (2000). Practice Problem for Creative Problem Solving. Waco, Texas: Prufrock Press, Inc.

J. Treffinger, D., G. Isaksen, S., \& Stend-Darval, K. B. (2006). Creative Problem Solving An Introduction. Waco, Texas: Prufrock Press, Inc.

Kementerian Pendidikan dan Kebudayaan. (2016). Buku Guru Matematika untuk SMP/MTs kelas VII Kurikulum 2013 revisi 2016. Jakarta: Pusat Kurikulum dan Perbukuan, Balitbang, Kemdikbud.

Khadafi, R. (2008). Atlas Kuliner Nusantara. Makanan Spektakuler 33 Provinsi (Cetakan Pertama). Jakarta: Bukune.

Kosasih, E. (2016). Strategi Belajar dan Pembelajaran Implementasi Kurikulum 2013 (Vol. Cetakan ke-3). Bandung: Yrama Widya.

Majid, A. (2015). Strategi Pembelajaran. Bandung: PT Remaja Rosdakarya. 
NCTM. (2000). Executive Summary Principles and Standards for School Mathematics. Retrieved from nctm.org

Ngalimun. (2017). Strategi Pembelajaran. Yogyakarta: Parama Ilmu.

Purwanto, E. W. (2017). Pengembangan LKS Berbasis Pemecahan Masalah Berdasarkan LangkahLangkah Polya untuk Kelas VII SMP Materi Aritmatika Sosial. Jurnal Ilmiah Mahasiswa FKIP Prodi Matematika, 2(1). Retrieved from http://ejournal.upp.ac.id/index.php/ mtkfkip/article/view/787

Rahayu, W. (2015). Model Pembelajaran Komeks: Bermuatan Nilai-Nilai Pendidikan Karakter Aspek Membaca Intensif di SD. Yogyakarta: Deepublish.

Rusman. (2014). Model-Model Pembelajaran. Jakarta: Rajawali Pers.

Saputra, E. (2012). Pengaruh Penggunaan Model Pembelajaran Anchored Instruction terhadap Peningkatan Kemampuan Komunikadi Matematis dan Self-Concept Siswa. Universitas Pendidikan Indonesia, Bandung.
Utomo, E. P. L., \& others. (2015). Analisis Kemampuan Kognitif dalam Memecahkan Masalah pada Pokok Bahasan Aritmatika Sosial Berdasarkan Taksonomi Solo Siswa Kelas VII SMP Negeri 4 Jember. Retrieved from http://repository.unej.ac.id/ha ndle/123456789/67396 